\title{
Learning English Motivation By Students of SMK UISU Medan
}

\section{Susi Ekalestari, Febriyola Putri, and Abdurrozzaq Hasibuan}

Universitas Islam Sumatera Utara (UISU), Medan, Indonesia

\section{Abstract}

This research is aimed to determine the type of motivation and factors that influence the motivation of the students of SMK UISU Medan. The sample of this study is all students of SMK UISU Medan. The total respondents in the sample are 52 students from first grade, second grade, and third grade of the school. This researach uses mixed method so that the data will be analyzed quantitatively and qualitatively using Likert scale. The instruments used in this reseaarch are questionnaire and interview. Therefore, the data are collected by sharing questionnaire and conducting. The research finds that the motivation most possessed by the respondents is instrumental motivation, furthermore, teacher's factor is the main factor that influences student motivation in learning English.

Corresponding Author:

Susi Ekalestari

susi.ekalestari@sastra.uisu.ac.id

Received: 1 July 2019

Accepted: 18 July 2019

Published: 31 July 2019

Publishing services provided by Knowledge E

(c) Susi Ekalestari et al. This article is distributed under the terms of the Creative Commons

Attribution License, which

permits unrestricted use and redistribution provided that the original author and source are credited.

Selection and Peer-review under the responsibility of the AICLL 2019 Conference Committee.
Keywords: Types of Motivation, Factor of Motivation, Students

\section{Introduction}

English is referred as an international language. The use of English becomes something obligatory if you want to get easiness in getting acces in the global information. In Indonesia, English is a compulsory subject that plays a role in improving the quality of education in Indonesia. A rapid development of science and technology and current globalization is getting stronger, so there is vast and tight competition in the field of education and occupation. One of the methods to face this condition is by improving the quality of education.

Education must involve teachers and students. In participating in the learning process, students certainly should have motivation to learn. "Motivation is not only important because it is a factor that causes learning, but also facilitates learning and learning outcomes" (Catharina, 2006: 157).Students who are highly motivated in learning will gain high learning outcomes. It means that the higher the motivation, the more the intensity of the effort made and the higher the learning outcomes he will get. Students make various efforts to increase success in learning to reach good achievement in learning 
learning process going. This matter makes students persistent in learning. Therefore, the researcher wants to examine more deeply about students' motivation in learning English. It is said that "Indonesian students fail in English subject even they have already been able to predict their bad score before the exam" (Ekalestari \& Pasaribu, 2017). In their research, they also found that students' anxiety affected the students' achievement in learning English in which the level of the anxiety was at moderate level. While in other research, related to students' perception in learning English, it was found that students has positive perception in learning English (Ekalestari, Nazri, Azmi, \& Putri, 2018). Knowing this, the researcher would like to know the motivation of the students in learning English. What triggers the researcher focus her research on motivation in learning English is that students had positive perception in learning English and the level of their anxiety in learning English was at moderate level, but in fact, they still got bad score in English subject. Therefore, the researcher would like to know the students' motivation in learning English in this research.

\section{Literature Review}

Basically motivation is an effort that is based on moving, directing and maintaining one's behavior to encourage doing something so as to achieve certain results and objectives. Motivation is the direct factor which leads to action. According to SnD'Andrade and SnStrauss (1992), "motivation is a product from interaction between external social aspect and internal psychological aspect. They indicated that motivation could be understood by social and cultural external environment as well as psychological need" (D’Andrade \& Strauss, 1992). By the same token, motivation of learning Korean could be interpreted by various reasons. Dörnyei (1998) noted that motivation for learning a foreign language connotes complicated and distinctive features owing to "the multifaceted nature and roles of language itself" Motivation is significant determinant of success in learning a second or foreign language. "It can be defined as driving force that pushes someone to do something" (Astuti, 2013, 14). Motivation is really important in learning second or foreign language. "Motivation could be considered as the emotion that a person could have towards learning a foreign language, and it is determined by his/her predisposition and personality characteristics." (Karahan, 2007, 2).Without motivation, it seems to be impossible to achieve success in foreign language learning (Aprianto, Nugroho, \& Mayda, 2015). So motivation of learning is a psychological condition that encourages students to learn happily and study seriously, which in turn will form a systematic learning method, full of concentration and can select the activities. It is said 
that "motivation is a very important and effective factor in the field of learning language" (Mahadi \& Jafari, 2012).

\subsection{Types of motivation}

According to SnGardner and Lambert (1972), postulated two major motivation orientations for language learning: integrative and instrumental. The integrative motivation means learning the language with the intention of participating in the culture of its people. And instrumental motivation suggests and implies that a learner learns the language in support of a purpose relating to occupation or further useful motive. These two types of motivation can affect and control the procedure and outcome of learning. According to them, integrative motivation guarantees the success of mastering foreign languages or English more that the other. This is caused by people who have integrative motivation have a positive attitude towards language they learned, so he was willing to do anything to be able to master the language. This type of person is actively practicing and does not depend solely on books or teachers. They always look for opportunities to be able to listen to foreign languages or English through broadcasts on radio or television, and are not shy or embarrassed to try to use that language in conversation. For them, learning a foreign language is not a thing which is difficult because they like it. Thus, the ability to master the language English because motivation is an important factor so you are proficient in English. Cook (2000) further believes that the integrative and instrumental motivation suggested by SnGardner and Lambert is useful and effective factor for second language learning. it is also said that integrative motivation plays an essential role in successful language learning. When the learners' attitudes and motivation towards the target culture is positive, the second language learners will easily accept and understand the target language.

Other perception of types of motivation is proposed by Saranraj SnL and Shahila SnZafar (2016). They classified motivation into four types. First, Intrinsic (Natural) Motivation. Intrinsic motivation refers to a force within the individual and it works from within the individual. It can be associated with the inner feelings of learners and it considers how learners engage in the task, and if they are willing to be involved in the activity. The rewards do not relate to external factors. Second, Extrinsic (Artificial) Motivation. Extrinsic motivation refers to environmental energizers like money, food, recognition, etc., which guide behaviour so as to attain a goal. It is driven by a desire for reward from outside: parents, employers, teachers or others. Third, Integrative Motivation. Integrative motivation plays an essential role in successful language learning. When the learners' 
attitudes and motivation towards the target culture is positive, the second language learners will easily accept and understand the target language. And fourth, Instrumental Motivation. Saranraj $L$ and Shahila Zafar also refers to the perception of Garder who said that "Instrumental motivation is related to learners' practical needs, such as getting a job, passing an exam or to get high income" (Gardner \& Lambert, 1977). Instrumental Motivation motivated learners to achieve a goal for their own satisfaction.

\subsection{Factors affecting motivation}

According to Malcom Brownlee (1993), the factors that affect the motivation in learning are: first, Teacher's Factor. A teacher must have competencies that can build student learning motivation in school, they are: Mastering teaching materials or materials, managing teaching and learning programs, class management, using media and learning resources, mastering educational foundations, manage teaching-learning interactions, assessing student achievement for teaching purposes, know the functions and guidance \& counseling programs, know and organize school administration, knowing the principles and interpreting the results of educational research for the benefit of teaching.

Second, Parents Factor. Based on research, parents give a major influence in motivating learning a child. Their influence on the development of children's learning motivation has a very strong influence on each development and will continue until the end of high school and after.

Third, Community Environmental Factor. Community environmental factors are places where students live are important elements in the process of forming student motivation, because students are also part or citizen of a community. Malcom Brownlee put forward a concept that shows this dependence by proposing "Humans in society and society in humans". Further explained that the concept of humans in society implies the dependence that individuals as part of a community have a social value system that is mutually binding and influencing each individual who lives together in a community, both urban communities and rural communities and or learning groups such as students at a school.

\section{Research Method}

The method used in this research is mixed methods. Mixed Methods is a research method which is based on the measurement of the quantity or statistical calculation and qualitative data that will be obtained from interview (Creswell, 2014). Mix methods can 
also be interpreted as a procedure for data collection, data analysis, with the combined use of sequential quantitative and qualitative methods or vice versa, in obtaining a deeper understanding of the main problems

\section{Result and Discussion}

\subsection{Result}

\subsubsection{Types of motivation}

As Saranraj SnL and Shahila SnZafar (2016) said that the type of motivation is classified into four types, then this research also covers the four types of motivation adopted. They are instrumental motivation, integrative motivation, intrinsic motivation and extrinsic motivation.

TABLE 1: Instrumental Motivation.

\begin{tabular}{l|l} 
No & Question \\
1 & $\begin{array}{l}\text { Knowing English will be helpful } \\
\text { for my career }\end{array}$ \\
2 & $\begin{array}{l}\text { I need to know English to enter } \\
\text { university } \\
\text { English will broaden my future } \\
\text { options }\end{array}$ \\
\hline 4 & $\begin{array}{l}\text { I learn english for practical } \\
\text { purposes } \\
\%\end{array}$ \\
\hline
\end{tabular}
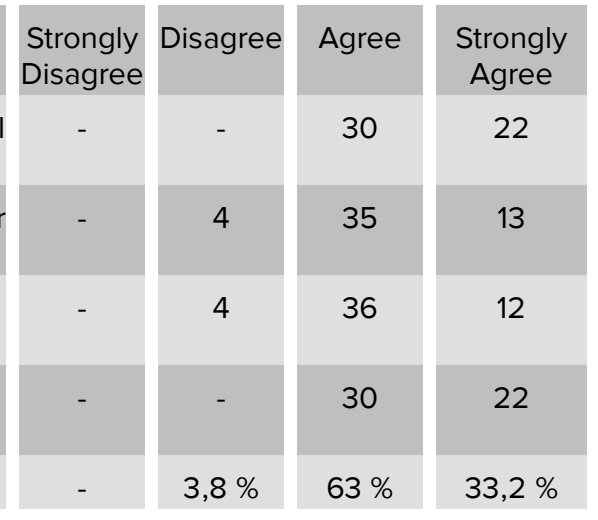

In table 1, it is seen that Instrumental Motivation owned by the students are $63 \%$ agree, $33,2 \%$ strongly agree, $3,8 \%$ disagree and no student has chosen strongly disagree.

TABLE 2: Integrative Motivation.

\begin{tabular}{|c|c|c|c|c|c|}
\hline No & Question & $\begin{array}{l}\text { Strongly } \\
\text { Disagree }\end{array}$ & Disagree & Agree & $\begin{array}{l}\text { Strongly } \\
\text { Agree }\end{array}$ \\
\hline 5 & $\begin{array}{l}\text { English helps me meet } \\
\text { foreigners }\end{array}$ & - & - & 31 & 21 \\
\hline 6 & $\begin{array}{l}\text { English helps me learn about } \\
\text { other culture }\end{array}$ & - & 8 & 32 & 12 \\
\hline 7 & $\begin{array}{l}\text { English helps me in my travels } \\
\text { overseas }\end{array}$ & - & - & 27 & 25 \\
\hline 8 & $\begin{array}{l}\text { I learn English to know more } \\
\text { about the world }\end{array}$ & - & - & 31 & 21 \\
\hline \multirow[t]{2}{*}{9} & $\begin{array}{l}\text { I learn English communicate } \\
\text { with others }\end{array}$ & 2 & 6 & 34 & 10 \\
\hline & $\%$ & $0,8 \%$ & $5,4 \%$ & $59,6 \%$ & $34,2 \%$ \\
\hline
\end{tabular}


Table 2 shows that Integrative Motivation owned by the students are 59,6\% agree, $34,2 \%$ strongly agree, $5,4 \%$ disagree and $0,8 \%$ disagree.

TABLE 3: Intrinsic Motivation.

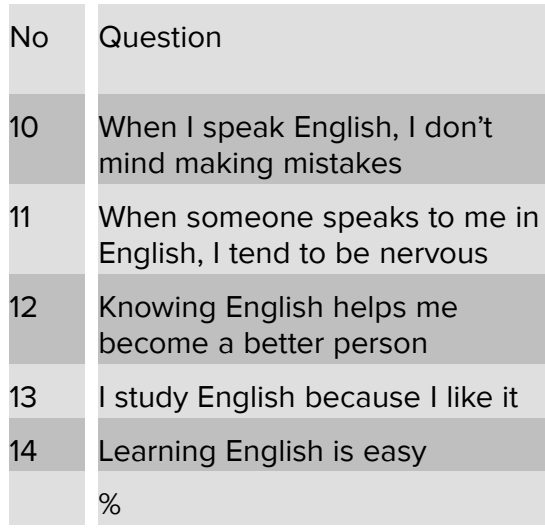

\begin{tabular}{|c|c|c|c|}
\hline $\begin{array}{c}\text { Strongly } \\
\text { Disagree }\end{array}$ & Disagree & Agree & $\begin{array}{c}\text { Strongly } \\
\text { Agree }\end{array}$ \\
\hline 1 & 27 & 22 & 2 \\
\hline 1 & 18 & 29 & 4 \\
\hline- & 7 & 36 & 9 \\
\hline- & 7 & 35 & 10 \\
\hline 2 & 23 & 21 & 6 \\
\hline $1,5 \%$ & $31,5 \%$ & $55 \%$ & $12 \%$ \\
\hline
\end{tabular}

Table 3 shows that Intrinsic Motivation owned by the students are 55\% agree, 12\% strongly agree, 31,5\% disagree, and 1,5\% strongly disagree.

TABLE 4: Extrinsic Motivation.

\begin{tabular}{|c|c|c|c|c|c|}
\hline No & Question & $\begin{array}{l}\text { Strongly } \\
\text { Disagree }\end{array}$ & Disagree & Agree & $\begin{array}{c}\text { Strongly } \\
\text { Agree }\end{array}$ \\
\hline 15 & $\begin{array}{l}\text { English is essential for } \\
\text { personal development }\end{array}$ & 1 & 3 & 39 & 9 \\
\hline 16 & $\begin{array}{l}\text { Others will have a better } \\
\text { opinion of me if I speak English }\end{array}$ & 1 & 5 & 37 & 9 \\
\hline 17 & $\begin{array}{l}\text { Knowing English gives me a } \\
\text { feeling of success }\end{array}$ & - & - & 34 & 18 \\
\hline 18 & $\begin{array}{l}\text { My family/friends encourage } \\
\text { me to learn English }\end{array}$ & - & - & 43 & 9 \\
\hline 19 & $\begin{array}{l}\text { I get help to do my homework } \\
\text { or get things explained to me } \\
\text { outside the class }\end{array}$ & - & 11 & 32 & 9 \\
\hline 20 & $\begin{array}{l}\text { Outside the class, I watch films, } \\
\text { listen to songs or read in } \\
\text { English }\end{array}$ & - & 17 & 25 & 10 \\
\hline 21 & $\begin{array}{l}\text { In an English class, the } \\
\text { teacher's personality is } \\
\text { important }\end{array}$ & - & 1 & 37 & 14 \\
\hline 22 & $\begin{array}{l}\text { In an English class, the } \\
\text { teacher's method is important }\end{array}$ & - & 1 & 36 & 15 \\
\hline 23 & $\begin{array}{l}\text { In an English class, the group } \\
\text { is important }\end{array}$ & - & 2 & 34 & 16 \\
\hline 24 & Outside the class, I use english & 2 & 27 & 19 & 4 \\
\hline 25 & I am motivated to learn English & 1 & 9 & 34 & 8 \\
\hline \multirow[t]{2}{*}{26} & $\begin{array}{l}\text { I wish my English class would } \\
\text { be different }\end{array}$ & - & 10 & 24 & 18 \\
\hline & $\%$ & $1,1 \%$ & $13,9 \%$ & $52,7 \%$ & $22,3 \%$ \\
\hline
\end{tabular}


Table 4 shows that the Extrinsic Motivation owned by students are 52,7\% agree, $22,3 \%$ strongly agree, $13,9 \%$ disagree, $1,1 \%$ strongly disagree.

\subsubsection{Factors of motivation}

Factors of motivation captured in this research are based on the factors of motivation proposed by Malcom SnBrownlee (1993). They are teacher's factor, parent's factor, and community environmental factor.

TABLE 5: Factors of Motivation.

\begin{tabular}{|l|l|c|c|c|c|} 
No & Factors & $\begin{array}{c}\text { Strongly } \\
\text { Disagree }\end{array}$ & Disagree & Agree & $\begin{array}{c}\text { Strongly } \\
\text { Agree }\end{array}$ \\
\hline 1 & Teacher's Factor & $0 \%$ & $6,7 \%$ & $63 \%$ & $30,3 \%$ \\
\hline 2 & Parent's Factor & $0 \%$ & $0 \%$ & $82.7 \%$ & $17,3 \%$ \\
\hline 3 & $\begin{array}{l}\text { Community Environmental } \\
\text { Factor }\end{array}$ & $0 \%$ & $0 \%$ & $59,6 \%$ & $40, \%$ \\
\hline
\end{tabular}

It is seen in table 5 that Teacher's factor is the most factor that influenced the students motivation in learning English. Teacher's factor gets 63\% agree, 30,3\% strongly agree, $6,7 \%$ disagree and no students chose strongly disagree. Parent's Factor gets $82,7 \%$ agree, $17,3 \%$ strongly agree, and no students chose disagree and strongly disagree. The last, the Community Environmental Factor gets 59,6\% agree, 40\% strongly agree, and no students chose disagree and strongly disagree.

The results of the Teacher's Factor were taken from 4 questions, Parent's Factor was taken from 1 question and Community Environmental Factors were taken from 1 question in the questionnare adopted from Saheb, V.

\subsection{Discussion}

\subsubsection{Types of motivation}

From the finding obtained by the researcher, it can be analyzed that most students own Instrumental Motivation because the Instrumental Motivation gets 63\% agree, 33,2\% strongly agree, 3,8\% disagree and no student has chosen strongly disagree. It is the highest percentage among others. Integrative motivation is the second most common type possessed by students. Integrative motivation gets 59,6\% agree, 34,2\% strongly agree, 5,4\% disagree and 0,8 \% disagree. The third is Extrinsic Motivation gets $52,7 \%$ agree, $22,3 \%$ strongly agree, $13,9 \%$ disagree, $1,1 \%$ strongly disagree. The last type of 
motivation is Intrinsic Motivation gets 55\% agree, $12 \%$ strongly agree, 31,5\% disagree, and $1,5 \%$ strongly disagree. It is the lowest percentage among others.

In other words, the students own all types of motivation proposed by Saranraj SnL and Shahila SnZafar (2016). Unfortunately, Intrinsic Motivation is not the most type of motivation that students have. According to Ryan \& Deci (2000) "Intrinsic motivation is not the only form of motivation, or even of volitional activity, but it is a pervasive and important one". Intrinsic motivation is the strength that comes from within oneself individually. Students who are intrinsically motivated will be willing to do all their activities not because of coercion or reward. In fact, the data shows that the respondents are lack of intrinsic motivation. This is the reason why students are not interested in learning English so they still get a bad score in English subject.

\subsubsection{Factors of motivation}

Based on the results obtained from the finding, it is analyzed that most of students choose teachers as the most important factor in learning English. The data shows that results of the open question contained in the questionnaire, $40.4 \%$ of students wrote that they will be more motivated to learn English if the teacher is able to provide the right teaching method for them. Some of them stated that the bad method and the fierce personality of the teacher were their main obstacles in learning English. These students want fun teaching methods so they not get bored easily during the class. This was confirmed by the teacher's statement in the interview that the school had not found the right effort to increase student learning motivation especially in English subjects.

Furthermore, the three factors of motivation adopted in this research are found. It means they influence the motivation of the respondents in learning English.

\section{Conclusion}

Based on the results of finding and analysis at this research, it can be concluded that the type of motivation that is mostly owned by students of SMK UISU Medan is Instrumental Motivation with $63 \%$ agree, $33.2 \%$ strongly agree, 3.8\% disagree and no student has chosen strongly disagree. The second type of motivation is Integrative Motivation, the third is Extrinsic Motivation, and the last is Intrinsic motivation. Intrinsic Motivation gets the lowest percentage. Unfortunately Intrinsic Motivation that is expected to play a major role in increasing student motivation in learning and increasing interest in learning from within the student individually showed the lowest percentage. This is the reason for the 
lack of interest in student learning especially in English subjects and the reasons why students still get a bed score in English subject.

The most influential factor in increasing student learning motivation is teacher's factor. As many as $40.4 \%$ of SMK UISU Medan students stated that they would be very interested in learning English if the teacher was able to provide the right and fun teaching method so they will not get bored. The teacher also confirmed that the school did not give good facility or effort to increase the students' motivation in learning English.

Finally, motivation is really important in learning English. Intrinsic motivation is the most important type to achieve what the students' wish by learning English. Furthermore, English teachers play important role to raise the intrinsic motivation of the students.

\section{References}

[1] Astuti, S. SnP. (2013). Teacher"s and student"s perception of motivational teaching strategies. TEFLIN Journal, 24 (2), 14- 31. Retrieved from http://www.journal.teflin.org

[2] Aprianto, M., Nugroho, B., \& Mayda, N. (2015). Motivational Strategies in Teaching English As Foreign Language: a Case Study in Junior High School 7 Kuningan, (2007), 82-93.

[3] Chatarina middlenameTri SnAnni. (2006). Psikologi belajar. Semarang: UPT Unnes Press.

[4] Cook, V. (2000). Linguistics and second language acquisition. Beijing: Foreign Language Teaching and Research Press and Macmillan Publishers Ltd.

[5] Creswell, J. SnW. (2014). Research Design: Qualitative, Quantitative, and Mixed Method Approach. California: SAGE Publications Ltd.

[6] SnD’Andrade, R. SnG., \& SnStrauss, C. (1992). Human motives and cultural models (Vol. 1). Cambridge: Cambridge University Press

[7] Dörnyei, Z. (1998). Motivation in second and foreign language learning. Language teaching, 31(03), pp. 117-135.

[8] Ekalestari, S., Nazri, M., Azmi, L., \& Putri, F. (2018). The Perception of Learning English by Undergraduate Students, 2018, 891-903. https://doi.org/10.18502/kss.v3i4.1995

[9] Ekalestari, S., \& Pasaribu, A. (2017). The Anxiety of Learning English by Senior High School Students in Medan, (2008), 715-721.

[10] SnGardner, R. SnC., \& Lambert, W. SnE. (1972). Attitudes and motivation in second language learning. Rowley, Mass.: Newbury House. 
[11] Karahan, F. (2007). Language attitude of Turkish students towards the English language and its use in Turkish context. Retrieved from http://jas.cankaya.edu.tr/ jas7/07-FIRDEFSKARAHAN.pdf

[12] Mahadi, T. S. T., \& Jafari, S. SnM. (2012). Motivation, Its Types, and Its Impacts in Language Learning. International Journal of Business and Social Science, 3(24), 230-235. Retrieved from http://ijbssnet.com/journals/ Vol_3_No_24_Special_Issue_December_2012/24.pdf

[13] Saranraj SnL and Shahila SnZafar, (2016). Motivation in Second Language LearningA Retrospect. Galaxy International Interdisciplinary Research Journal, 4(1), 7-13. Retrieved from https://www.researchgate.net/publication/291790630 